\title{
Sven Wernström
}

"Vi Fixar Allt"-böckerna av Stig Ahl (fem böcker, 1959-1964) är nog inte så kända idag, men för mig var de viktiga. De påminner lite om Astrid Lindgrens Mästerdetektiven Blomkvist, och det handlar om ett kamratgäng som löser mysterier. Fast i de här böckerna är huvudpersonerna i tonåren, alla är pojkar och det hela är betydligt mer arbetslivsorienterat!

Arbete, ja: "Vi Fixar Allt" handlar egentligen om ett gäng unga entreprenörer och egenföretagare som utför mindre reparationer och service-sysslor, och som på köpet snubblar över brott och mysterier. Långt före ROT- och RUT-avdrag, skapar böckernas Tommy, Hammy, Leffe och Kurre arbetstillfällen på egen hand. Det låter udda, men för mig var den ingången mer inspirerande än själva mysterierna. Och jag var inte ensam om att tänka så. En av mina kamrater startade en egen version av fixar allt, och jag hjälpte gärna till när det var möjligt. Det var en viktig erfarenhet.

När jag läste Vi Fixar Allt-böckerna visste jag inte att Sven Wernström var en av författarna bakom pseudonymen "Stig Ahl" (den andra var Stig Malmberg). Men om jag vetat hade det ökat min respekt för författaren ytterligare. I min bokhylla hade jag redan flera av böckerna om Flygkamraterna (de äldsta efter min far), men också nyare böcker som Trälarna och Resa på okänd planet. Både historia och science fiction hörde till mina favoritämnen.

Det slår mig nu när jag skriver den här introduktionen till Barnbokens temanummer om Sven Wernström att "Vi Fixar Allt" skulle kunna fungera som devis för Wernströms författarskap över huvud taget.

Det finns i Wernströms böcker en utopisk optimism och tro på människors möjligheter - inte minst unga människors - att förbättra sina och andras livsvillkor. Detta gäller oavsett om man tittar på den tidiga genrefiktionen eller senare mer politiskt medvetna böcker. Visserligen är den sene Wernström ofta samhällskritisk, men det är en konstruktiv kritik som syftar till att skapa det goda samhället, ingen cynisk svartsyn. När människor är solidariska och använder teknik och kunskap för att göra världen bättre, ja då "fixar vi allt".

Man kan också stanna upp vid "Vi"-et. I Wernströms böcker finns nästan alltid ett "Vi": ett trälar-vi, ett flygkamrat-vi, ett fixar-allt-vi. Det är gruppen som är viktig (man frestas skriva "vi-ktig"), inte den 
enskilde; det är kollektivet, inte individen. Även i det här fallet menar jag att vi-et finns i både de äldre och nyare böckerna. Det är också värt att notera att Wernströms egen författargärning i högre utsträckning än många andras är ett vi. Stig Ahl är ett sådant vi. Wernström skrev även nio flickböcker under de kollektiva pseudonymerna "Siv Malmström" och "Sonja Berg" (även dessa samförfattade med Stig Malmberg).

Slutligen kan författarskapet som helhet karaktäriseras som ett vi fixar allt. Här ryms både pojk-, flick- och djurböcker. Där kan man hitta historieböcker och science fiction, detektivhistorier och reseskildringar. En del är skrivet för att underhålla, annat för att upplysa. Där finns bruksprosan och de politiska brandtalen. I hans verk-katalog finns kanske inte allt, men sannerligen det mesta. (Och skulle man fråga efter någon särskild genre, skulle han nog kunna fixa det med.)

Fixar-attityden till skrivandet är också befriande tycker jag. Skrivandet är ett arbete, ett hantverk. Det ges inget utrymme för romantiserade idéer om inspiration och geni i Wernströms författarskap. Med en sådan no nonsense-inställning är det lättare att själv sätta sig vid datorn än om man ska invänta gudomliga ingivelser. I Wernströms fall har skrivmetoden lett till ett imponerande livsverk - kvantitativt förstås, men ofta också kvalitativt. För även när det gäller skrivande är det ju så att kvalitet ofta är en följd av kvantitet. För att bli en bra författare måste man skriva mycket.

I det här temanumret av Barnboken skrapar vi på ytan av Wernströms verklista. Jerry Määttä tar sig an Wernströms science fiction. Där behandlas framför allt de tidiga Flygkamrater-böckerna, men utvikningar görs också mot de senare böckerna i genren. Määttä visar bland annat i sin artikel vilken roll Wernström spelade i etablerandet av SF-genren i Sverige.

Olga Holownia skriver om översättningen och mottagandet av Wernström på Island. Fokus i hennes artikel ligger på Wernströms kontroversiella Jesus-skildring i Kamrat Jesus. Även om kritiska röster hördes även i Sverige när det gällde Kamrat Jesus så var det en mild västanfläkt i jämförelse med det ramaskri som utbröt på Island med Félagi Jésus.

En annan kontrovers står i centrum för Tommy Gustafssons bidrag, nämligen den svenska censurens ingripande när den danska TV-dramatiseringen av Trälarna första gången visades på svensk TV. Gustafsson gör en media-analys där han jämför olika mediers benägenhet att censureras. Gustafsson reflekterar också över 
1970-talets politiska och estetiska radikalism i jämförelse med tidigare och senare decennier.

Slutligen skriver Maria Andersson om Wernströms rekontextualisering av Selma Lagerlöfs Nils Holgersson i Den underbara resan. Hur skriver Wernström fram nationen? På vilka sätt tar han spjärn mot den äldre, kanoniska texten?

Det här numret av Barnboken "fixar inte allt" när det gäller Wernströms rika produktion. Det saknas fortfarande studier av många av hans böcker - och av hans författarskap som helhet. Ja, det finns saker att göra, mysterier att lösa.

Det hade de gillat, Tommy, Hammy, Leffe och Kurre - och alla de andra.

Björn Sundmark 